\title{
DESIGNING AND IMPLEMENTING A NATIONAL DATA SYSTEM FOR ELEMENTARY AND SECONDARY EDUCATION - A PERSPECTIVE FROM THE NETHERLANDS
}

\author{
J. SCHEERENS * and A. J. VISSCHER $\dagger$ \\ *Foundation for Educational Research in the Netherlands and \\ †Twente University of Technology
}

Commenting on the plans for a national system in the U.S.A. from the perspective of a small country like the Netherlands reminds us of the mouse and the elephant tramping across the bridge: "What a noise we are making!" said the mouse. However, even if the quantitative scope of the issue in the Netherlands corresponds more closely to state-level in the U.S.A., the practical problems of designing and implementing a central data system are to some extent the same. In any one country the focus on specific problem areas (political, organizational and managerial, and even technical) will vary according to the particular circumstances, so, after a brief sketch of Dutch developments in areas related to creating a national data-system, we shall conclude this commentary by indicating those aspects which emerge from the Dutch perspective and which may be pertinent to the U.S.A.

One difficulty, specific to our own country, has been that for a long time the most influential parties within the 'pedagogical province' in the Netherlands remained unconvinced of the benefits of large-scale product evaluations and assessment programs. During the seventies there was considerable mistrust of large-scale quantitative outcomemeasurement, the substantive argument being that this kind of information could not do justice to the complexities of individual schools and the experiences of individual teachers, while the political argument in the background was that central evaluation might be deleterious to our schools' autonomy, a constitutionally established feature of education in the Netherlands. $\$$

It should be noted, however, that longitudinal studies at the national level by the Central Bureau of Statistics (CBS), focused on the school careers of pupils in secondary education, have been in progress since 1965 . This shows that data-collection is regarded as less debatable when it is less directly associated with evaluation. A general shift in orientation occur-

¥The authors are indebted to Drs. A. J. Blommers from the Central Bureau of Statistics for providing useful information and to Mrs Christine Thirlway for linguistic editing.

$\$$ Scheerens, J. (1985). Contextual influences on evaluations: the case of innovative programs in Dutch education. Educational Evaluation and Policy Analyses 7, 309-317. 
red during the early eighties when there was growing concern for the quality of education. A government-memorandum on this theme was issued in 1981. * At present there are several projects in various stages of implementation all of them seeking to establish national data bases. We have divided them into four groups.

\section{National Evaluation Projects}

Operational evaluation plans are now being prepared within the context of two national educational programs: the development of integrated secondary education and the new educational priorities policy (i.e. a national program for compensatory education, comparable to the former American ESEA title I program). Both evaluation plans propose outcome-, process-, input- and context-measurement, with a specific emphasis on achievement and attainment outcome-evaluation.

\section{A National Assessment Project}

Following the governmental memorandum on the quality of education, in 1981, a pilotproject was started to establish the feasibility of a national assessment project in elementary education. The pilot-project was quite successful. $\dagger$ The most important stake-holders in the educational system expressed their approval of a full-fledged assessment program, which is now in preparation as a joint effort of the National Centre for Test Development (CITO) and the Foundation for Educational Research (SVO). Smaller scale pilot-projects are also in progress on the extension of the assessment project to secondary schools and investigation into the possibilities of a computerized network of testing services.

\section{Various Projects of the Central Bureau of Statistics (CBS)}

The Central Bureau of Statistics maintains several data-bases of descriptive statistics on primary, secondary and higher education: systematic data-bases on schools, data-bases on school personnel and data-bases on students. Apart from these 'regular' data-bases the CBS has carried out several special projects, among which the national longitudinal cohort studies in secondary education have been used most frequently for research purposes. $\neq$ These cohort studies include data on socio-economic background of pupils and educational attainment.

"The government report "Quality of education" (in Dutch: De Kwaliteit van het onderwijs). Department of Education, 1981.

†Wesdorp, H. et al., De haalbaarheid van Peridiek Peilings-onderzoek. Een voorstudie op net gebied ran het taalonderwijs in de lagere school. Lisse: Swets \& Zeitlinger, 1986.

$\ddagger$ The "from year to year cohort" of 1965. The "SMVO"-cohort of 1977 (school career, and social background of pupils in secondary education) and the SLVO-cohort of 1982. 


\section{The Development of School Information Systems (SCHOLIS)}

In 1985 the government took the initiative of exploring the possibilities of implementing computerized information systems in secondary schools. These information systems are designed to assemble data useful for administrative and managerial purposes (e.g. financial data, registration of absenteeism, data concerning the time table). Although the SCHOLIS project started out as a school-based enterprise, there are now plans to connect the school systems with each other and with a governmental information system. It is recognised however, that some important technical and political problems will have to be dealt with when the attempt is made to interconnect the school-based information systems.

From these recent endeavours it can be concluded that in Holland too the awareness of the benefits of national information systems on the state of affairs of education is growing. Since many of the individual projects are still in their preparatory phases, the idea of trying to integrate them from the start is particularly appealing. There are, however, some characteristics inherent to the Dutch educational system, which could prove to be severe handicaps to the design and implementation of a national data system. First of all, educational policy-making and decision-making in the Netherlands is a particularly complicated affair, in the sense that most decisions have to be negotiated among institutionalized pressure groups. ${ }^{*}$ This implies not merely a severe limitation of centralized policy-making, but also a lack of clear patterns for delegation of authority to lower administrative levels. It is therefore an open question whether a national data system on education may not be experienced (for right or wrong) as too centralistic a supportive device of educational policymaking, and whether the overall problem of gearing it to certain levels of educational decision-making can be easily solved.

In the second place it will be difficult to find an appropriate institutional basis for the management of a national data system. In this respect we feel that cooperation between the institutes now involved in the projects we have already mentioned (CBS, CITO, SVO and several university based task forces) would not be the major problem. A more tricky aspect, in our opinion, would be the role of the central bureaucracy of the Ministry of Education. We feel that, although there should be close cooperation with the ministry, as an important information user, government officials should not be involved in the actual data system management, as this would endanger the political independence of the national data system.

Experience has shown, however, that government officials in the field of education are generally reluctant to delegate managerial responsibilities when projects like this are at stake. $+\mathrm{A}$ final problem-area that we feel would be a major issue of concern for a national data system in the Netherlands is the cooperation from schools. Because Dutch schools do not have a tradition of testing and because there is still some anti-measurement feeling among certain educationalists, and because of our schools' jealously-guarded autonomy, considerable effort would be required to convince a sufficient number of schools of the benefits of a national data system.

\footnotetext{
*Compare: J. M. G. Leune "Decision-making within the educational system" (in Dutch) - in: J. A. van Kemandade (Ed.) Onderwijs, bestel en beleid (1981), Wolters-Noordhoff.

†Scheerens, J. (1985) Organization and management of educational evaluation-projects in The Netherlands, In B.P.M. Creemers (Ed.) Evaluation Research in Education. The Hague: SVO Selecta Series.
} 
Our basic assumption in these comments has been that comprehensive data feedback is a vital asset of any educational system directed towards improvement. What the Dutch perspective reveals is the importance of recognizing the political and organizational constraints when we envisage an integrated, centralized information centre.* A mixture of a 'top-down' and 'bottom-up' approach in designing the system - thus trying to meet information demands at various levels of the educational system - might solve some of these problems. In such an approach, we believe that the question of an optimal level of globality/specificity of the data would be one of the most important categories of design decision.

We are hopeful that the work that has been carried out in the American "elementary/ secondary education data redesign project" will be an inspiration for the developments which are going on in our country.

*The fact that our comments are mainly concerned with the political problems surrounding the inception of a national data system does not mean that the technical problems have escaped us. We are certainly aware of the difficulties involved in connection with, for example, establishing information needs, demands on software, accuracy of measurement and finding the optimal format for feeding information back to the various user groups. 